\title{
Cylinder liner wear as a function of selected physicochemical indicators of engine oil
}

ARTICLE INFO

Received: 13 July 2021

Revised: 31 August 2021

Accepted: 1 September 2021

Available online: 1 September 2021

The paper presents a new method of forecasting the durability of piston-rings-cylinder (PRC) liner assembly of the internal combustion engine on the basis of observed changes of physical and chemical properties of engine oil. Methods used so far for the durability evaluation of the PRC group required collecting information about the moments when the assembly reached its boundary state or used kinetic models of wear designed using accelerated research of real objects. In the proposed method, for the evaluation of durability of engine cylinders information gathered form engine oil is used. Course of changes of the proposed index of change intensity of kinematic viscosity at the temperature of $100^{\circ} \mathrm{C}-\mathrm{Cv} 100$ allows for evaluation of the durability of PRC assembly of an IC engine. Obtained value was positively verified using forecasting method related to the technical criteria based on the assessment of the wear intensity.

Key words: engine durability, forecasting, operational research

This is an open access article under the CC BY license (http://creativecommons.org/licenses/BY/4.0/)

\section{Introduction}

Designing of modern internal combustion engines is a challenge both in terms of their efficiency, production and operation ecology, as well as high durability. The last parameter, despite the bench and operational tests carried out by the manufacturer, is finally verified at the stage of use in natural operating conditions. Reliable information about the actual durability of the vehicle, including its engine, can only be obtained at this stage. On the one hand, this requires a long waiting time for the expected test results (sometimes several years), and on the other, proposing non-invasive methods of testing wear, so that the tribological processes in the observed kinematic nodes are not disturbed.

In case of an automotive vehicle, a component very important taking into account car's durability is a piston-ringscylinder (PRC) assembly. Wear of this assembly directly influences reaching by the engine its borderline state (SG) [8]. Wear of the PRC group is mostly identified with the increase of the internal diameter of the cylinder liner. As the diameter increases, engine start becomes more difficult and engine delivers less power - these are technical criteria of SG. Moreover, engine consumes more fuel and lubricating oil. Increase in oil consumption, with severe regulations concerning exhaust emissions, results in the fact, that the engine (even fulfilling other criteria) can not be used any longer - these are economic and ecologic criteria of SG [7].

Considering possibilities of durability evaluation of the frictional couple (of the technical object), two methodical variants can be considered [5, 6, 14]:

1. An analysis of object's operation time (e.g. PRC assembly) till reaching boundary state. Having results of research for sufficiently high, homogenous population of objects, it is possible to estimate for any time moment $\mathrm{t}$ wear distribution taking into account average, maximum and minimum wear. A particular time of operation is the moment when the system reaches boundary wear, conditioning boundary state which corresponds to the durability of the object. Recording the particular moments of reaching boundary state allows for establishing the average durability $\overline{\mathrm{T}}$, minimum $\mathrm{T}_{\min }$ and maximum $\mathrm{T}_{\max }$ for the given population. This method (a'posteriori) in case of PRC assembly is difficult to realize. Such type of research allows for determination of numerical and functional characteristics (point and range) with given probability. This method is however costly and time consuming, and obtained results can be transferred on objects of similar class only with certain approximation. Fig. 1 presents the determination of object's durability using the method described above.

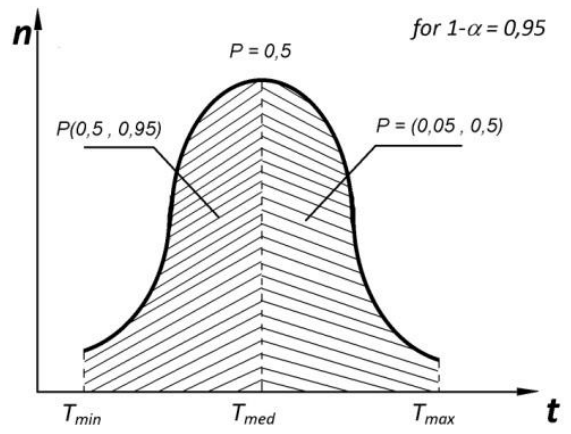

Fig. 1. Determination of durability using a'posteriori method

2. Second of methods allows for significant shortening of research time and creates possibility to forecast durability a'priori. In case of this method, research is done in a shorter time than object's service life. It includes an analysis of individual realizations of wear process and estimation of tendencies in the course of phenomena (theoretical models are obtained). Having information regarding boundary state, an assessment of object's durability can be done. The condition of correctness of the estimation is the calculation of tendencies of average wear and possible minimum and maximum values for the given confidence level. This theoreticallyexperimental methods of durability estimation belong to 
the group of accelerated research, as - from the assumption - they do not require any tests till the object reaches its boundary state. Gathered information about the kinetics of changes of wear characteristics (models of wear kinetics) allow for forecasting durability on the basis of theoretical reliability models of the distribution of correct time of operation. The idea of such type of assessment is shown on Fig. 2a, 2 b.

a)

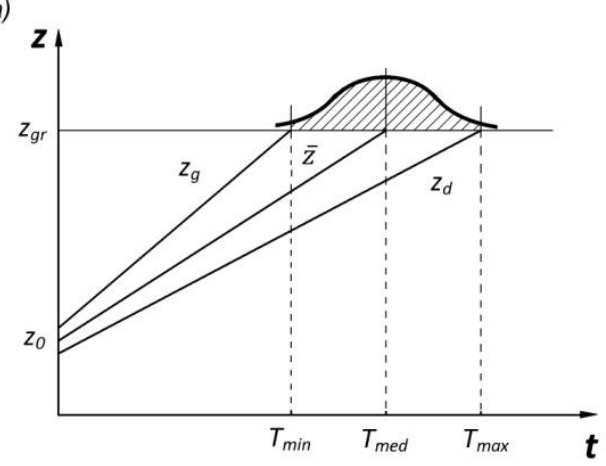

b)

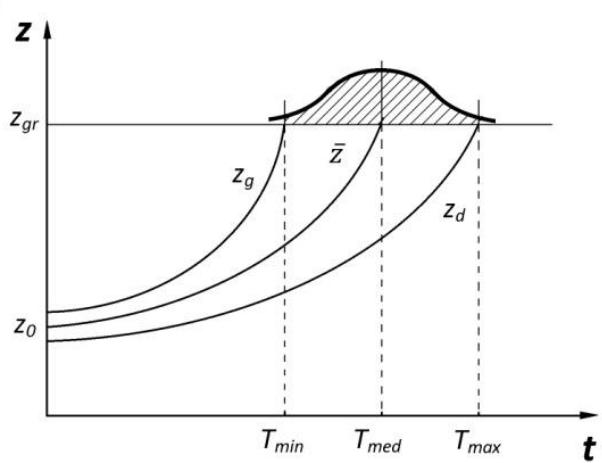

Fig. 2. Schematic presentation of durability assessment using a'priori method

\section{Essence of the method}

As mentioned above, the reliability of the results of the wear tests of the engine's kinematic systems is related to the limitation of interference in the operated unit. Also, the measurement methods used should interfere with the tribological system as little as possible, or even not cause temporary changes in its environment, disrupting the functioning of the system.

For the evaluation of the durability of the PRC assembly, methods used so far require research till the object reaches its boundary state (methods a'posteriori), or require intervention in the tribological system so as to determine object's regular service time, e.g. micro measurements, method of artificial bases, isotopic methods. A new method described below eliminates these disadvantages.

For the durability evaluation of cylinder liners information gathered from engine oil is used. Engine oil has important function forming with the engine a tribological system [7]. Changes in physical and chemical properties of oil result from the influence of the system and are strictly related to its technical condition, i.e. wear of cylinder liners.

The levels of specific physical and chemical properties of engine oil affect the quality and range of functions performed by the oil and, as such, they are a prerequisite for its suitability for a particular type of engine. Among the parameters and physicochemical quantity levels outlined in subject standards and literature, the preference is given to the kinematic viscosity and dynamic viscosity (some of the basic properties of fluids). Kinematic viscosity is always stipulated in the quality requirements relating to lubricating oils. It can increase or decrease during operation. An increase in viscosity is generally connected with progressive oxidation processes at elevated temperature, and a decrease with the shear of oil. The assessment of oil viscosity allows the user to estimate the time between oil changes [2, 11-13].

Currently, it is possible to observe the phenomenon of extending the service life of the oil in the engine. This applies to both mileage and calendar time. This significantly reduces environmental pollution with used petroleum products, but the most important aspect should be to ensure the correct operation of the lubricated kinematic nodes in terms of the properties of the lubricant in the tribological system. You can meet with research carried out in this area.

According to the current state of knowledge, the quality of engine oil can be determined through a series of tests, which include laboratory evaluation of the physicochemical properties, as well as through assessing its particular properties which, however, entails lengthy and costly operational research. Knowledge and understanding of the characteristics of motor oils and developing effective methods of analysis enables the creation of systems of quality monitoring which may be conducted within the life cycle of the engine [13].

A number of studies have been conducted to scientifically measure the quality of engine oils. Inayatullah et al. [3] used the technique of acoustic emission to analyze engine oil viscosity. Karpovich et al. [4] attempted to develop a universal instrument to measure and control the quality of motor oils. Their evaluation of the quality and condition of engine oil was centered around viscosity as a key performance indicator. Agoston et al. [1], on the other hand, have focused in their research on thermal aging of engine oils. They have shown that oil evaporation and oil burning have the most significant impact on the process of aging, thus leading to the loss of its key properties, which inevitably affects the overall performance of the engine oil [13].

The method of durability evaluation of engine cylinders presented here, in general assumption is designed for the use by a wide group of users who do not have sufficient technical and diagnostic resources. Therefore oil exchange service can be used to gather information about:

- parameters of new oil,

- parameters of used oil,

- oil operation time in an engine.

On the basis of above data it is possible to determine value of index of change intensity of oil properties $C_{W}(1)$ :

$$
\mathrm{C}_{\mathrm{W}}=\frac{\mathrm{w}_{\mathrm{p}}-\mathrm{W}_{\mathrm{k}}}{\mathrm{t}_{\mathrm{ol}}} \text { for } \mathrm{t}>0
$$

where: $\mathrm{W}_{\mathrm{p}}$ - value of the measured index of oiltechnical condition for the new oil, $\mathrm{W}_{\mathrm{k}}$ - value of the measured index of oil technical condition for the used oil (at exchange), $\mathrm{t}_{\mathrm{ol}}-$ oil operation time in the engine (till exchange), $\mathrm{C}_{\mathrm{W}}-$ index of change intensity of oil properties. 
This index brings averaged information about intensity of engine impact on the oil. It does not take into account periodic changes in the value of measured oil parameter, and reflects long term tendency in observed changes. Periodic changes of measured index can result from, among others, the fact of topping up oil as a effect of oil loss (leaks, combustion). Detailed analysis of index changes in such case would lead to erratic evaluation of diagnostic information. Long term observation of index of change intensity of oil properties and observed its changes allow to conclude, that the reason of these variations are wear processes occurring in the engine. Graphic interpretation of described phenomena is shown on Fig. 3.

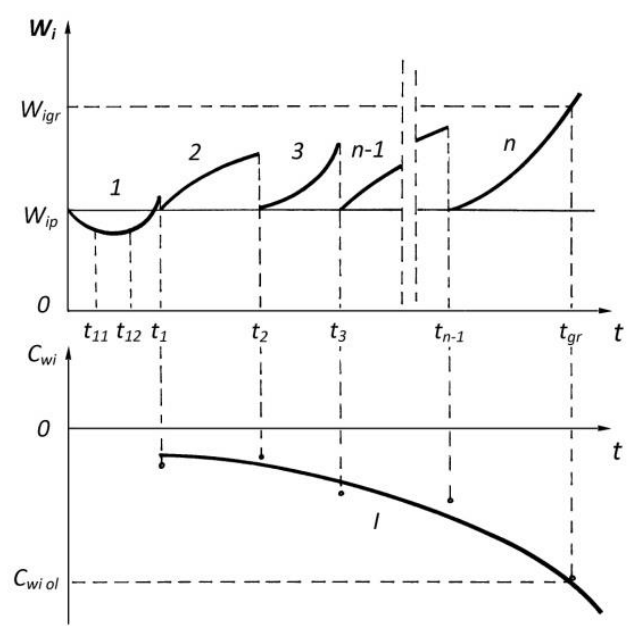

Fig. 3. Graphic interpretation of changes in the index of change intensity of oil properties: $\mathrm{W}_{\mathrm{p}}-$ preliminary index value, $\mathrm{W}_{\mathrm{k} 1}, \mathrm{~W}_{\mathrm{k} 2}, \ldots, \mathrm{W}_{\mathrm{kn}}-$ end value of index of oil technical condition at the moment $1,2, \ldots, \mathrm{n}$ of oil change, $t_{1}, t_{2}, \ldots, t_{n}-$ moments of oil change in the engine, $C_{W}-$ index of change intensity of oil properties

Curves $1,2,3, \ldots, \mathrm{n}$ represent changes of observed index of oil technical condition $\mathrm{W}_{\mathrm{ol}}$ in the time between oil changes $t_{1}, t_{2}, t_{3}, \ldots, t_{n}$. Detailed analysis of momentary index values for the time points $t_{11}, t_{12}, t_{21}, t_{22}, \ldots, t_{n 1}$ and calculated on this basis momentary values of index of change intensity of oil properties $\mathrm{C}_{\mathrm{Wch}}$ do not carry any important diagnostic information in the sense of technical condition engine wear. They result from the influence of momentary or short term inputs acting on the engine (increase of load, technical service) or directly on the engine oil (topping up new oil, outside impurities resulting from filter damage). However analysis of changes in the longer research period (between oil changes) permits to observe long term tendency of changes - curve I. Fig. 3 shows also marked position of index boundary value. It is a intersection of curve I with the value corresponding to the lower permissible value of index of change intensity of oil properties $\mathrm{C}_{\mathrm{W}}$. In this case, it is related to the reaching of the upper permissible value of observed index of oil condition $\mathrm{W}$ - value resulting from accepted criteria of boundary state. In situation, when value of the observed index of oil condition decreases $\left(\mathrm{W}_{\mathrm{k} 1}\right.$, $\mathrm{W}_{\mathrm{k} 2}, \ldots, \mathrm{W}_{\mathrm{kn}}<\mathrm{W}_{\mathrm{p}}$ ), reaching boundary state will result from crossing upper boundary value of index $\mathrm{C}_{\mathrm{W}}$, related to lower permissible value of the index of oil condition $\mathrm{W}$.
Fig. 3 shows hypothetical realization (changes of values of oil properties index) related to the single object (engine) under operation. In reality, for every individual object from the investigated sample from the population obtained results are scattered. Therefore the dependence describing variability of the index of change intensity of oil properties can be only of stochastic value - correlative.

The dispersion area is limited by regression curves $\mathrm{C}_{\mathrm{Wimax}}$ and $\mathrm{C}_{\mathrm{Wi} \text { min }}$ corresponding to the upper and lower border of confidence interval. Specific values depend from the arbitrary assumption of confidence interval (for technical purposes $0.9 ; 0.95 ; 0.99)$ - Fig. 4 .

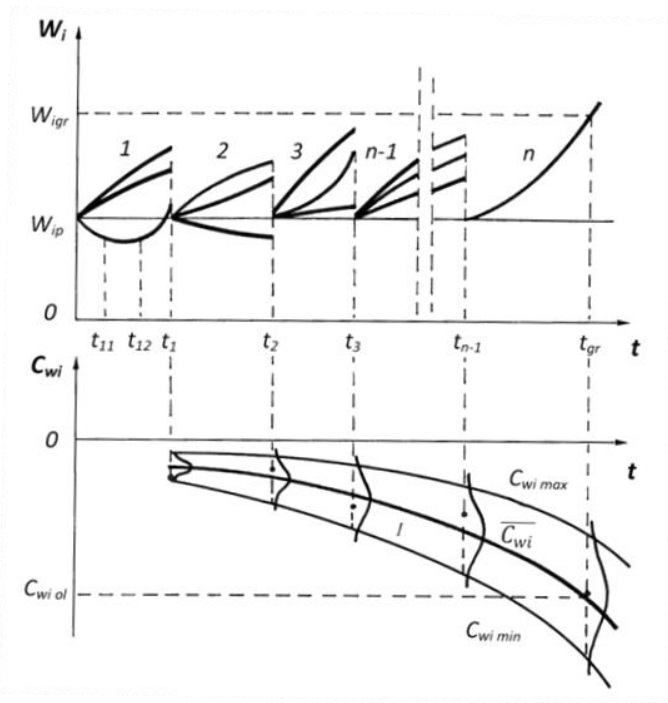

Fig. 4. Graphic interpretation of changes in the index of change intensity of oil properties for the population of objects: $\mathrm{W}_{\mathrm{p}}$ - preliminary index value, $\mathrm{W}_{\mathrm{k} 1}, \mathrm{~W}_{\mathrm{k} 2}, \ldots, \mathrm{W}_{\mathrm{kn}}$ - end value of index of oil technical condition at the moment $1,2, \ldots, n$ of oil change, $t_{1}, t_{2}, \ldots, t_{n}-$ moments of oil change in the engine, $\mathrm{C}_{\mathrm{W}}$ - index of change intensity of oil properties

Changes in engine oil presented on Figs. 3 and 4 take place parallel to the wear of cylinder liners of the engine. Mathematical description of this phenomena is created by three curves reflecting expected value of changes $\bar{z}$ (calculated on the basis of operational research), upper border of realization of the stochastic wear $\mathrm{z}_{\mathrm{g}}$ and lower border of the wear course $z_{d}$. These three equations all together create statistic model of wear process of cylinder liners (Fig. 5).

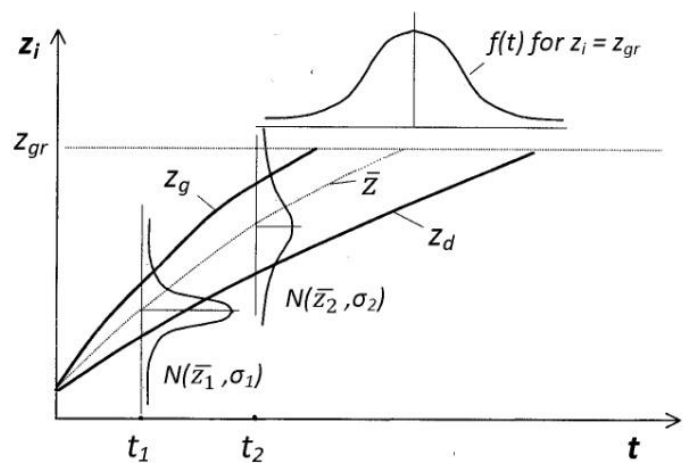

Fig. 5. Graphic interpretation of mathematical model of wear process of the cylinder liners 
Such description of wear process permits - for any time moment $\mathrm{t}$ - to determine width of confidence interval on the confidence level $\beta$, where real realizations of the stochastic process are located. Choice of confidence interval is a matter of decision. Boundaries of the confidence interval for the results related to the time of observation $t_{1}$ can be written as follows:

$$
\begin{aligned}
& \mathrm{z}_{1}^{\mathrm{g}}=\overline{\mathrm{z}_{1}}+\mathrm{q}_{\beta} \cdot \sigma_{1} \\
& \mathrm{z}_{1}^{\mathrm{d}}=\overline{\mathrm{z}_{1}}-\mathrm{q}_{\beta} \cdot \sigma_{1}
\end{aligned}
$$

where: $\mathrm{q}_{\beta}$ - proportionality coefficient.

Value of the coefficient $\mathrm{q}_{\beta}$ should be determined (in relation to the batch size of the results set) according to the rules of building the range estimators.

Making use of engine oil as a source of information for forecasting engine durability is possible only when it can be proved, that the kinetics of changes of chosen physical and chemical properties of the oil reflects wear changes taking place in the analyzed PRC assembly. Confirmation of such correlation can be done on the basis of comparable values of estimated durability of the cylinder liner with the use of "wear" as well as "oil" method. Operational research should be done, so as to determine course of curves I (Fig.4) and $\bar{z}$ (Fig. 5).

\section{Results of experiments}

The proposed test method was verified on the basis of the results of measurements of the wear of cylinder liners of engines performed as part of supervised operation tests. The subject of the research was five compression-ignition engines with direct fuel injection, in-line cylinder arrangement, installed in medium-duty trucks. The amount of wear of individual cylinder liners was recorded for the mileage of 0-250 thousand $\mathrm{km}$ in intervals of approx. 50 thousand $\mathrm{km}$. Technical maintenance was done according to the manufacturer's instructions.

So as to determine course of the curve $\bar{z}$ in used engines, periodically micro-measurements of cylinder liners was done, according to the standard recommendation of the branch norm [9]. Additionally during obligatory technical inspections united with oil change service, oil samples were taken from the engine and put under physical and chemical analysis. Basic physical, chemical and functional indexes of the used oil were determined.

On the basis of gathered information it was possible to obtain equations for the expected value and for the lower and upper boundaries of the wear process realization. Full mathematical description of the wear process of the cylinder liners for the period of operation $t>t_{d}\left(t_{d}-\right.$ runningin) is shown by the set of equations (3):

$$
\begin{array}{r}
\overline{\mathrm{z}}=(0.000132) \cdot \mathrm{t}+43.961[\mu \mathrm{m}] \\
\mathrm{z}_{\mathrm{d}}=\min \{0.000105 \cdot \mathrm{t}+43.961 \mid 0.000132 \cdot \mathrm{t}+38.466\} \\
\mathrm{z}_{\mathrm{g}}=\max \{0.000159 \cdot \mathrm{t}+43.961 \mid 0.000132 \cdot \mathrm{t}+49.456\}
\end{array}
$$

where: $\mathrm{t}$ - engine operation time (mileage) $[\mathrm{km}]$.
Similar analysis was made in case of research results obtained for the used oil. It was concluded - on the basis of theoretical analysis and statistical analysis of research results, that the best index for the evaluation of changes in oil properties is kinematic viscosity at the temperature of $100^{\circ} \mathrm{C}$ and corresponding index of change intensity of kinematic viscosity at $100^{\circ} \mathrm{C}-\mathrm{C}_{\mathrm{v} 100}$ (equation (1)). Course of $\mathrm{C}_{\mathrm{v} 100}$ changes in a function of operation time is given by the dependence (4):

$$
\mathrm{C}_{\mathrm{v} 100}=(3.277)-(2.142) \cdot \mathrm{t}^{(0.033)}\left[\frac{\mathrm{mm}^{2}}{\mathrm{~s} \cdot \mathrm{km}}\right]
$$

where: $\mathrm{t}$ - engine operation time (mileage) $[\mathrm{km}]$.

Using equations (3) and (4) durability of PRC assembly for the engine under test was determined. In case of technical criterion, durability of the system results from reaching permissible value of cylinder liner wear. This value was accepted on the basis of work [11]. In case of "oil" criterion, boundary values of kinematic viscosity $\mathrm{v}_{100}$ were accepted using the norm BN-77/0535-46 [10]. Then boundary value of $\mathrm{C}_{\mathrm{v} 100 \mathrm{gr}}$ index was calculated, which was later used

\begin{tabular}{|c|c|c|c|c|c|c|}
\hline \multirow{2}{*}{$\begin{array}{c}\text { Data } \\
\text { source }\end{array}$} & \multirow{2}{*}{$\begin{array}{l}\text { Type of } \\
\text { criterion }\end{array}$} & \multicolumn{2}{|c|}{ Limit state parameter } & \multicolumn{3}{|c|}{$\begin{array}{l}\text { Durability } \\
\times 10^{3}[\mathrm{~km}]\end{array}$} \\
\hline & & $\begin{array}{l}\text { Parameter de- } \\
\text { scription }\end{array}$ & $\begin{array}{l}\text { Limit } \\
\text { value }\end{array}$ & $\mathrm{T}_{\min }$ & $\mathrm{T}_{\text {śr }}$ & $\mathrm{T}_{\max }$ \\
\hline own & technical & $\begin{array}{l}\text { cylinder liner wear } \\
\overline{\mathrm{z}} \text { at depths } 20,35, \\
50,95[\mathrm{~mm}] \text { in the } \\
\text { plane A-A and } \\
\text { B-B }\end{array}$ & $\begin{array}{c}126 \\
{[\mu \mathrm{m}]}\end{array}$ & 516.0 & 621.5 & 781.3 \\
\hline own & oil & $\begin{array}{l}\text { index of intensity } \\
\text { of changes in } \\
\text { kinematic viscosi- } \\
\text { ty of engine oil in } \\
\text { temperature } \\
100^{\circ} \mathrm{C}-\mathrm{C}_{\mathrm{v} 100}\end{array}$ & $\begin{array}{c}-0.066 \\
{\left[\frac{\mathrm{mm}^{2}}{\mathrm{~s} \cdot \mathrm{km}}\right]}\end{array}$ & - & 630.2 & - \\
\hline
\end{tabular}
for the determination of cylinder liners durability on the basis of oil criterion. Results of calculations are presented in Table 1.

Table 1. Comparison of forecasts of cylinder liners durability of the $359 \mathrm{M}$ engines

\section{Conclusions}

Presented oil criterion takes into account possibilities of correct evaluation of mating of components in the PRC assembly with regard to the type of friction. One of conditions of fluid friction is, for instance, existence of appropriate crevice between mating components in relation to the viscosity of used lubricant. Increase of clearance between components of PRC assembly intensifies degradation processes taking place in engine oil, and thus, faster change of its viscosity. Proposed method of forecasting tribological durability using results of current (in kinetic sense) assessment of oil properties, gives results regarding average durability which are comparable with results determined according to the forecasting method related to the technical criterion. Values of forecasted durability average $621.5 \cdot 10^{3} \mathrm{~km}$ using technical criterion and $630.2 \cdot 10^{3} \mathrm{~km}$ for the oil criterion. So, basing on the information describing technical condition of the used lubricant it is possible, with no need of interference in the monitored PRC assembly, to deter- 
mine durability of the cylinder liners (on the accepted confidence level). Moreover simple measurement methods away from the investigated object are used, and with no need of taking the engine out of service.

\section{Nomenclature}

PRC piston-rings-cylinder

\section{Bibliography}

[1] AGOSTON, A., ÖTSCH, C., JAKOBY, B. Viscosity sensors for engine oil condition monitoring - Application and interpretation of results. Sensors and Actuators A: Physical. 2005, 121(2), 327-332.

https://doi.org/10.1016/j.sna.2005.02.024

[2] GOMÓŁKA, I., AUGUSTYNOWICZ, A. Evaluation of applicability of dielectric constant in monitoring aging processes in engine oils. Eksploatacja $i$ Niezawodnosc Maintenance and Reliability. 2019, 21(2), 177-185.

https://doi.org/10.17531/ein.2019.2.1

[3] INAYATUllaH, O., JAMALUDIN, N., ALI, A. et al. Application of acoustic emission technique to observer the engine oil's viscosity. $2^{\text {nd }}$ International Conference on Instrumentation Control and Automation. IEEE 2011, 344348. https://doi.org/10.1109/ICA.2011.6130184

[4] KARPOVICH, I.A., ODZHAYEV, V.B., AZARKO, I.I. et al. Universal device for motor-oil quality control. 11th International Conference Microwave and Telecommunication Technology. Conference Proceedings (IEEE Cat. No01EX487). 2001, 673-674.

https://doi.org/10.1109/CRMICO.2001.961712

[5] KHANIYEV, T., BASKIR, M.B, GOKPINAR, F. et al. Statistical distributions and reliability functions with type-2 fuzzy parameters. Eksploatacja i Niezawodnosc - Maintenance and Reliability. 2019, 21 (2), 268-274. https://doi.org/10.17531/ein.2019.2.11

[6] NADOLNY, K. Podstawy modelowania niezawodności materiałów eksploatacyjnych, Nadolny K. (red.), Seria: Biblioteka Problemów Eksploatacji, Wyd. ITeE, Radom 1999.

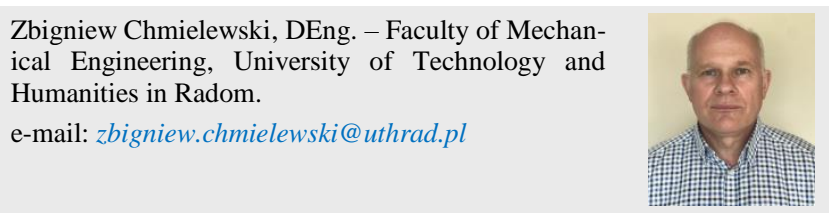

SG borderline state

[7] NIEWCZAS, A., RYMARZ, J., DĘBICKA, E. Stages of operating vehicles with respect to operational efficiency using city buses as an example. Eksploatacja i Niezawodnosc - Maintenance and Reliability. 2019, 21(1), 21-27. https://doi.org/10.17531/ein.2019.1.3

[8] NIEWCZAS, A. Trwałość zespołu tłok-pierścienie tłokowecylinder silnika spalinowego. WNT. Warszawa 1998.

[9] Norma BN-79/1374-04. Silniki samochodowe. Badania stanowiskowe. Badania niezawodności.

[10] Norma BN-77/0536-46. Ocena stopnia przepracowania olejów do silników z zapłonem samoczynnym.

[11] URZĘDOWSKA, W., STĘPIEŃ, Z. Wybrane zagadnienia dotyczące zmian właściwości silnikowego oleju smarowego w eksploatacji. Nafta-Gaz. 2012, 12(LX), 1102-1110.

[12] WOLAK, A., JANOCHA, P. Zmiany właściwości użytkowych olejów silnikowych w warunkach eksploatacji - analizy FTIR. Nowoczesne środki smarowe do specjalistycznych zastosowań $w$ urzadzeniach przemystowych, transporcie $i$ komunikacji. Kraków: Instytut Nafty i Gazu - Państwowy Instytut Badawczy. 2015, 201, 84-105.

[13] WOLAK, A., ZAJĄC, G. The kinetics of changes in kinematic viscosity of engine oils under similar operating conditions. Eksploatacja i Niezawodnosc - Maintenance and Reliability. 2017, 19(2), 260-267. https://doi.org/10.17531/ein.2017.2.14

[14] YAN, S., MA, B., ZHENG, C. Health index extracting methodology for degradation modelling and prognosis of mechanical transmissions. Eksploatacja i Niezawodnosc Maintenance and Reliability. 2019, 21(1), 137-144. http://dx.doi.org/10.17531/ein.2019.1.15 